\title{
Somatic pairing, endomitosis and chromosome aberrations in snakes (Viperidae and Colubridae)
}

\author{
MARIA LUIZA BEÇAK, WILLY BEÇAK and ALEXANDRE PEREIRA \\ Laboratório de Genética, Instituto Butantan, 05503-900 São Paulo, SP, Brasil \\ Manuscript received on August 26, 2002; accepted for publication on May 7, 2003; \\ contributed by WILLY BEÇAK*
}

\begin{abstract}
The positioning of macrochromosomes of Bothrops jararaca and Bothrops insularis (Viperidae) was studied in undistorted radial metaphases of uncultured cells (spermatogonia and oogonia) not subjected to spindle inhibitors. Colchicinized metaphases from uncultured (spleen and intestine) and cultured tissues (blood) were also analyzed. We report two antagonic non-random chromosome arrangements in untreated premeiotic cells: the parallel configuration with homologue chromosomes associated side by side in the metaphase plate and the antiparallel configuration having homologue chromosomes with antipolar distribution in the metaphase ring. The antiparallel aspect also appeared in colchicinized cells. The spatial chromosome arrangement in both configurations is groupal size-dependent and maintained through meiosis. We also describe, in untreated gonia cells, endomitosis followed by reductional mitosis which restores the diploid number. In $B$. jararaca males we observed that some gonad regions present changes in the meiotic mechanism. In this case, endoreduplicated cells segregate the diplochromosomes to opposite poles forming directly endoreduplicated second metaphases of meiosis with the suppression of first meiosis. By a successive division, these cells form nuclei with one set of chromosomes. Chromosome doubling in oogonia is known in hybrid species and in parthenogenetic salamanders and lizards. This species also presented chromosome rearrangements leading to aneuploidies in mitosis and meiosis. It is suggested that somatic pairing, endomitosis, meiotic alterations, and chromosomal aberrations can be correlated processes. Similar aspects of nuclei configurations, endomitosis and reductional mitosis were found in other Viperidae and Colubridae species.
\end{abstract}

Key words: snakes, somatic pairing, chromosome positioning, endomitosis, diplochromosomes.

\section{INTRODUCTION}

The polemic question whether chromosomes have a non-random positioning or a casual distribution in the nucleus is a matter of importance regarding some epigenetic events as non-random chromosome rearrangements, non-disjunctions, and genetic imprinting. The idea of a fixed chromosome location arose from early cytogenetic evidences as in Drosophila

\footnotetext{
*Member of Academia Brasileira de Ciências Correspondence to: Dra. Maria Luiza Beçak E-mail: mlbecak2003@yahoo.com
}

(Dobzhansky 1936) indicating that the relative positions of the chromosomes remain the same through mitosis. In this species of Diptera homologue chromosomes present the peculiar somatic pairing phenomenon. Another interesting evidence showing that chromosomes have fixed location was the visualization of homologue chromosomes positioned in opposite halves of the metaphase plate. This aspect observed in early embryogenesis of a turbellarian (Costello 1970) indicated the occurrence of an ordered chromosome transmission from gametes to 
following generations. Non-random chromosome distribution and somatic pairing were also evidenced in uncultured cells from Chinese hamster (Juricek 1975). Electronmicroscopy data from human fibroblast cells also indicated the occurrence of a nonrandom spatial positioning of the chromosomes (Mosgöller et al. 1991). Fluorescence in situ hybridization (FISH) studies in prometaphase rosettes of human cells also claimed that chromosomes are fixed located with the homologues separated from each other by at least $90^{\circ}$ (Nagele et al. 1995). Conflicting with this view is the evidence that chromosomes do not have a fixed position in the nuclei, as reported in experiments of in situ hybridization and three-dimensional reconstruction (Manuelidis and Borden 1988). More recently, fluorescence in situ hybridization (FISH) studies also showed that in human cells there is a relatively random array of chromosomes on the mitotic ring (Allison and Nestor 1999). According to these authors, a fixed location of the chromosomes on the mitotic ring is not required for mitotic distribution. Furthermore, the relative positions of the chromosomes on each metaphase ring are most likely carried through anaphase into telophase. According to Rabl's suggestion (1885), the relative positions of the chromosomes in somatic metaphase rings would be a reflection of their locations in interphase. Moreover, later investigations showed that the relative positions of the chromosomes are comparable in prophase and metaphase nuclei (Bajer and MolèBajer 1981, Hiraoka et al. 1990). Alternatively, it has been shown that in interphase the relative positions of the chromosomes may be affected by gene activity (Manuelidis and Borden 1988). In Drosophila melanogaster, bromodeoxyuridine incorporation and DNA quantification in combination with fluorescence in situ hybridization (FISH) were used to analyze aspects of heterochromatin, the Rabl configuration and pairing of homologue chromosomes. The chromosomes showed a dynamic behavior in interphase, the Rabl configuration appearing only about $2 \mathrm{~h}$ after mitosis, the somatic pairing being distorted during S-phase more rapidly for a euchromatic than for a heterochromatic region (Csink and Henikoff 1998). According to Sun et al. (2000), two biophysical models could explain chromosome positioning. In the volume exclusion model, a non-random size dependent spatial positioning is explained by steric hindrance among chromosomes. In the mitotic preset model confirmed by their findings, the size-dependent positioning is established and maintained in mitosis and G1 interphase.

Data on the spatial placement of chromosomes in mitosis and meiosis of snakes are lacking in the literature. This fact can be attributed to the difficulty to identify the microchromosomes by standard methods and to obtain G-bands. Most cytogenetic analysis in snakes are based in C and NOR bands studies using colchicinized nuclei. A complete study of premeiosis and meiosis is laborious because cell cycle is seasonal and female meiotic cells are scarce. Several results in other organisms addressed to the question whether premeiosis would influence chromosome pairing in meiosis (Bennett 1984). In this paper we study chromosome spatial arrangement in mitotic, premeiotic, and meiotic cells of Bothrops jararaca and B. insularis. Premeiosis is here considered in a wide sense as a period previous to first meiosis division appearance. Considering that spindle inhibitors as colchicine and Colcemid may distort chromosome order in nuclei (Juricek 1975), we studied chromosome positioning in uncultured mitotic and meiotic cells not subjected to these agents. The aspects obtained in both sexes were compared with those obtained in colchicinized nuclei. The analysis included only the macrochromosomes. We describe the occurrence of two non-random and antagonic types of chromosome distribution in somatic metaphases of these species. The first type, found only in colchicine untreated gonia cells, is similar to the somatic pairing known in Diptera. The second type, that is characterized by the bipolarity of the homologues in the metaphase plate, appeared in colchicine treated cells from spleen, intestine and blood, and in untreated nuclei from gonia cells. The two types of configurations present a groupal size- 
dependent chromosome distribution that is maintained in meiotic cells. We also describe the presence of premeiotic endomitosis followed by reductional mitosis in both species. Moreover we report alterations in the meiotic mechanisms and the occurrence of chromosome aberrations in B. jararaca.

Previous studies in Viperidae species using colchicinized cells showed that the karyotypes of Bothrops species have conserved morphology and chromosome number including eight pairs of macrochromosomes $(\mathrm{M})$ and ten pairs of microchromosomes $(\mathrm{m}), 2 \mathrm{n}=16 \mathrm{M}+20 \mathrm{~m}$. The eight pairs of $\mathrm{M}$ are recognized by size and ordered in karyotypes according to two groups of larger and smaller macrochromosomes each with four pairs. The sexpair is the fourth of the karyotype (ZZ, male and ZW, female) (Beçak W et al. 1962, Beçak W 1968). Chromosome $\mathrm{C}$ banding in B. insularis is telomeric and centromeric in all macrochromosomes and in the $\mathrm{Z}$, being the microchromosomes totally heterochromatic. The $\mathrm{W}$ chromosome is polymorphic presenting different size and $\mathrm{C}$ band. The smaller $\mathrm{W}_{1}$ type found in females is entirely heterochromatic. The larger $\mathrm{W}_{2}$ type found in intersexes is variegated with positive and negative $\mathrm{C}$ bands. This $\mathrm{W}_{2}$ chromosome appeared dicentric with variation of $\mathrm{C}$ band pattern. Polymorphism of the $\mathrm{W}$ chromosome also occurs in $B$. jararacussu, a related species from the continent. The abnormal sex phenotypes and the altered fertility in $B$. insularis females were attributed to chromosomal rearrangements probably created by insertion sequences in the W (Beçak ML et al. 1990). This possibility was previously indicated to explain the occurrence of multiple sex-chromosomes of Bungarus caeruleus (Elapidae) (Singh et al. 1979). ZW sex bivalent of $B$. jararaca females segregates reductionally in the first meiosis division and equationally in the second division (Beçak ML and Beçak W 1981). Meiotic cells of B. jararaca show 4 or 5 microchromosomes associated with the nucleolus (Beçak W et al. 1966). Bothrops insularis NOR-bands were identified on the short arm of four microchromosomes (Beçak ML et al. 1990). Differential activity of ribosomal cistrons during development was shown in another species of the same genus, $B$. alternatus. Although the karyotypes of adult animals do not exhibit satellites, chromosomes 5 and 6 revealed satellites during embryo development (Beçak ML and Beçak W 1973). Presence of NOR bands in two microchromosomes, in macrochromosome number 6 , or just in one homologue of chromosome 6 and one microchromosome was also described in B. neuwiedi subspecies. Moreover, molecular analysis of DNA repeats of these species demonstrated a highly conserved organization of the ribosomal repeats in the total genomic DNA (Trajtengertz et al. 1995).

Our observations on nuclei configuration, endomitosis and reductional mitosis were extended to other Bothrops species whose karyotypes are known: B. jararacussu, B. moojeni $(2 \mathrm{n}=36$ ) (Beçak $\mathrm{W}$ 1968), and to the colubrid species Thamnodynastes strigatus $(2 \mathrm{n}=32)$, Spilotes pullatus $(2 \mathrm{n}=36)$ (Beçak W and Beçak ML 1969), and Philodryas nattereri $(2 \mathrm{n}=36)$. The karyotype of this later species will be described elsewhere. Among Colubridae species there are a wide variation of chromosome number and different levels of sex-chromosome differentiation. Morphologically differentiated sexchromosomes appear in the $4^{\text {th }}$ pair (Beçak W 1968). Some Philodryas species show secondary constriction in pair five (Beçak ML et al. 1971). As $P$. chamissonis exhibits NOR in the long arm of pair 2, it was proposed that translocation of insertion type may be accounted for polymorphisms in this genus (Moreno et al. 1987).

\section{MATERIALS AND METHODS}

Chromosome positioning in B. jararaca was studied in colchicine untreated metaphases (spermatogonia and oogonia) from 11 specimens being $10^{7}$ from Santa Catarina State (Canoinhas), $40^{\top}$ from São Paulo State (Ibiuna, Jundiaí, Juquitiba and Cotia), $2 \sigma^{7}$ from Paraná State, and $2 \sigma^{7}$ and 29 from unidentified origin. The chromosomes were obtained by the standard squash technique and stained with Giemsa. Chromosome location was also an- 
alyzed in colchicinized lymphocytes obtained from short-term blood cultures (Beçak W et al. 1962) from $1 \sigma^{7}$ and 4 \% . The male and one female of this sample came from Canoinhas, being the other animals of unidentified origin. In the case of $B$. insularis, chromosome positioning was studied in colchicinized nuclei of cultured lymphocytes and of uncultured cells (spleen and intestine) from $4 \circ^{x}, 3$ 우 and $6 \phi^{7}$ and in untreated spermatogonia nuclei from $10^{7}$. The specimens of B. insularis came from Queimada Grande Island (São Paulo State). Chromosome location was studied in karyotyped nuclei whose centromeres were plotted in diagrams of metaphase plates. Only macrochromosomes location was analyzed.

Endomitosis was studied in B. jararaca and $B$. insularis with the same untreated animals used for chromosome positioning. The analysis of meiosis in $B$. jararaca was carried out with untreated nuclei from the same animals used for chromosome positioning plus $1 \sigma^{\top}$ from Juquitiba. Meiotic cells of this species were AgAs stained according to Vidal and Mello method (1995), including treatment with Triton X-100 prior to staining. This pre-treatment did not remove nuclear proteins potentially reactive to the AgNOR method and improved the positive images.

Chromosome positioning and endomitosis were also studied in untreated spermatogonia from $10^{7}$ of Thamnodynastes strigatus from Piedade (São Paulo State), $1 \sigma^{\top}$ of Spilotes pullatus from São Manoel (São Paulo State) and $1 \sigma^{7}$ of Philodryas nattereri from Tocantins State, all belonging to the Colubridae family. All the animals were anesthetized before death.

\section{RESULTS}

\section{Parallel and Antiparallel Chromosome}

\section{LOCATION IN Bothrops}

Chromosome location in Bothrops jararaca was studied in 75 metaphases obtained from 24 colchicinized lymphocyte nuclei (from $1 \sigma^{7}$ and 4 \%) and from 51 untreated spermatogonia and oogonia nu- clei (from $90^{\top}$ and $2 \%$ ). In B. insularis this study included 88 metaphases obtained from 76 colchicinized lymphocytes, spleen, and intestine nuclei (from $4 \sigma^{x}, 3 q$ and $6 q^{x}$ ) and from 12 untreated spermatogonia nuclei (from $10^{x}$ ).

Two antagonic types of chromosome positioning were found in both species. The antiparallel type showed homologue chromosomes located in opposite halves of the metaphase plate (Figure 1A). This bipolarity can be total including the eight pairs of macrochromosomes, or incomplete. The parallel type exhibited homologue chromosomes associated side by side in a closely parallel location in the metaphase plate (Figure 1B). The number of associated homologues varied in nuclei. The antiparallel aspect appeared in both colchicine treated nuclei (from lymphocytes, spleen, and intestine) and in untreated nuclei (from gonia cells). The parallel configuration was detected only in colchicine untreated nuclei (from gonia cells).

The number of each type of nuclei configuration was estimated in both species. In B. jararaca, among 51 untreated metaphases, 8 presented total bipolarity and 5 showed total parallelism. Treated metaphases of this species showed only antiparallelism. Among 24 treated nuclei, 11 presented total bipolarity. In B. insularis, colchicinized nuclei exhibited only the antiparallel configuration, total or incomplete. Among 76 of these nuclei, 23 showed total bipolarity. Both parallel and antiparallel configurations appeared in untreated spermatogonia nuclei of this species. Among 12 untreated nuclei of the male studied, 1 metaphase showed total bipolarity and 2 revealed total parallelism.

The peculiar parallel positioning found in untreated gonia cells of B. jararaca and B. insularis, was also found in untreated spermatogonia of $B$. jararacussu and B. moojeni (Figure 3A).

\section{ENDOMITOSIS}

Endomitosis was found in untreated oogonia and spermatogonia of B. jararaca, B. insularis, B. jararacussu, and B. moojeni. Endoreduplicated chromosomes appeared thick or exhibited diplochromo- 

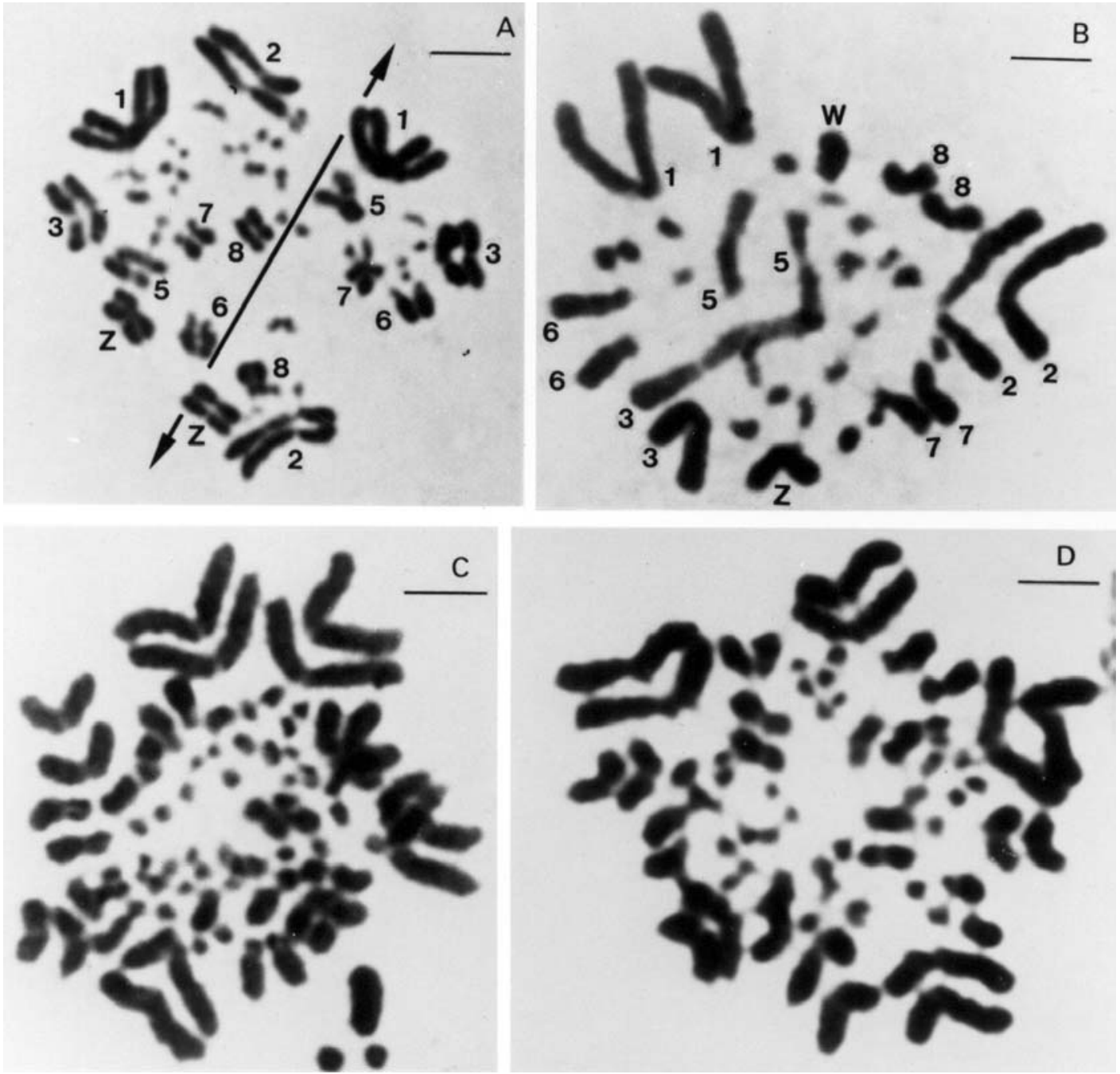

Fig. 1 - Nuclei configurations and endomitosis in colchicine untreated cells of Bothrops species $(16 \mathrm{M}+20 \mathrm{~m})$ : A. Antiparallel chromosome location in a spermatogonia metaphase (B. jararaca; male 28; axis delimits the two halves of the metaphase plate; bar $=8.9 \mu \mathrm{m})$. B. Parallel positioning of all macrochromosomes with exception of pair $4(\mathrm{ZW})$ in a oogonia metaphase. Pair 3 presents homologues differing in size $($ B. jararaca; female 8 ; bar $=7.9 \mu \mathrm{m})$; C. Endoreduplicated spermatogonia metaphase $($ B. jararaca; male 12; bar $=7.8 \mu \mathrm{m})$; D. Endoreduplicated spermatogonia metaphase (B. insularis; bar $=7.1 \mu \mathrm{m})$.

some structure (Figures 1C and 1D). Different levels of ploidy were found from the most frequent $4 \mathrm{n}$ to the $16 \mathrm{n}$ which was found less frequently. Endopolyploidy was also found in Thamnodynastes strigatus, Spilotes pullatus, and Philodryas nattereri.The endoreduplicated nuclei presented a series of mitoses leading to an increase of cell number and to a reduction of chromosome number restoring the $2 \mathrm{n}$ level (Figures 2A to 2D).

\section{Groupal Size-Dependent Chromosome} Positioning IN Bothrops

Somatic and meiotic metaphases of Bothrops species usually present the group of the larger macrochromosomes located on the periphery of the plate, circumscribing the group of smaller macrochromosomes (Figures 3A and 3C). The microchromosomes of snakes from different families are cen- 

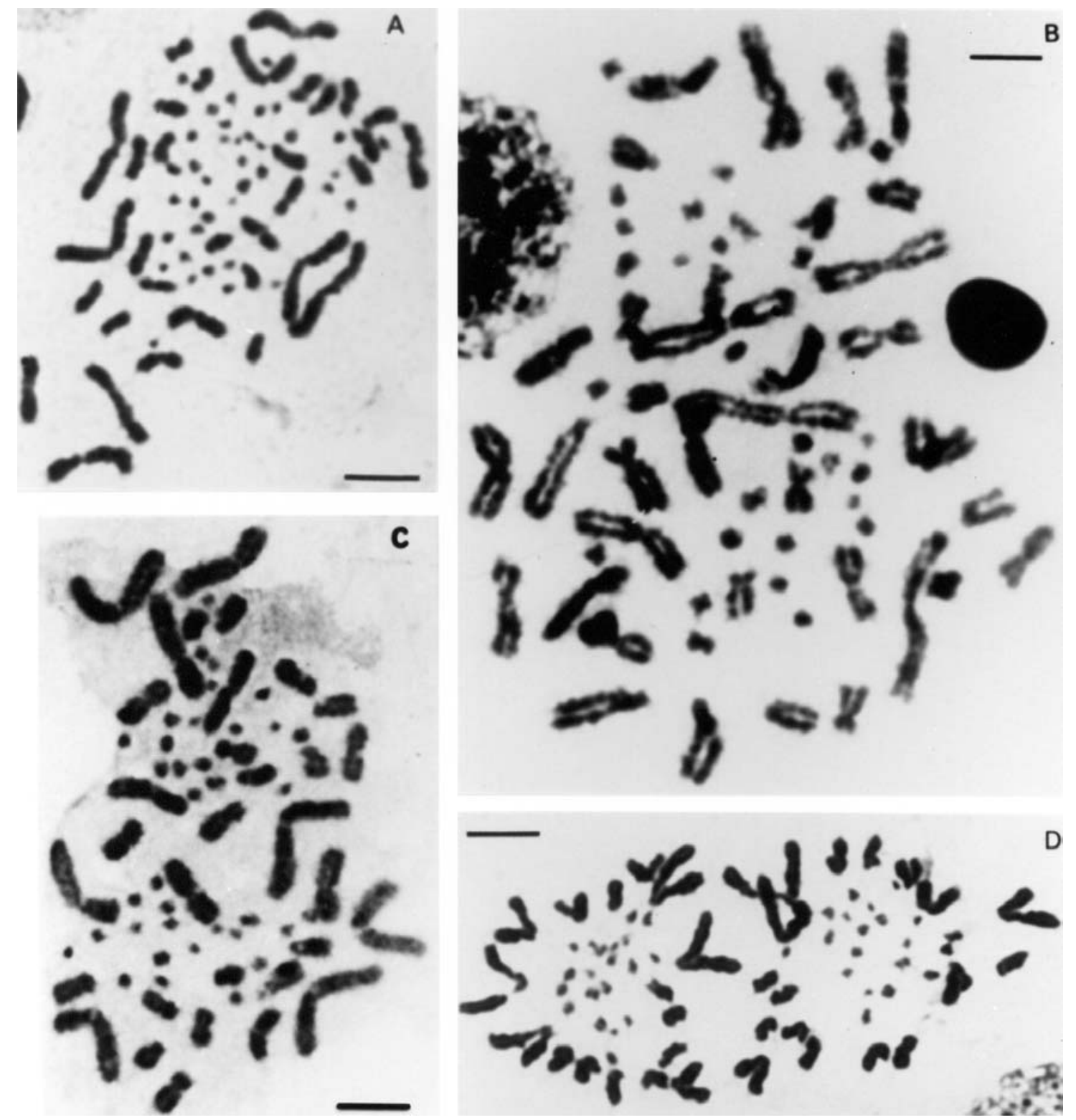

Fig. 2 - Endomitosis in Viperidae and Colubridae: A. An endoreduplicated metaphase with splitted diplochromosomes (Bothrops jararaca; male 41 from Juquitiba; bar $=10.2 \mu \mathrm{m})$; B. A $4 \mathrm{n}$ metaphase of Thamnodynastes strigatus, $($ male; bar $=10.2 \mu \mathrm{m})$; C. A $4 \mathrm{n}$ metaphase $($ B. jararaca; male 15; bar $=14.3 \mu \mathrm{m}) ; \mathrm{D}$. Two daughter 2n metaphases $($ Bothrops jararacussu; male; bar $=11.4 \mu \mathrm{m})$.

trally located in most metaphase plates (Figures 2D and 3D) (White 1973). The distinct groupal-size location of larger and smaller types of macrochromosomes also account for asymmetric nuclei configurations in meiotic and mitotic anaphases of $B$. jararaca (Figures 3B and 3D).
Structural Diplochromosomes in B. jararaca

An interesting aspect found in B. jararaca males (2n $=16 \mathrm{M}+20 \mathrm{~m}$ ) was that endoreduplicated nuclei can divide, segregating one complete set of macrochromosomes including eight diplochromosomes to each pole. Each diplochromosome of the daughter nuclei 

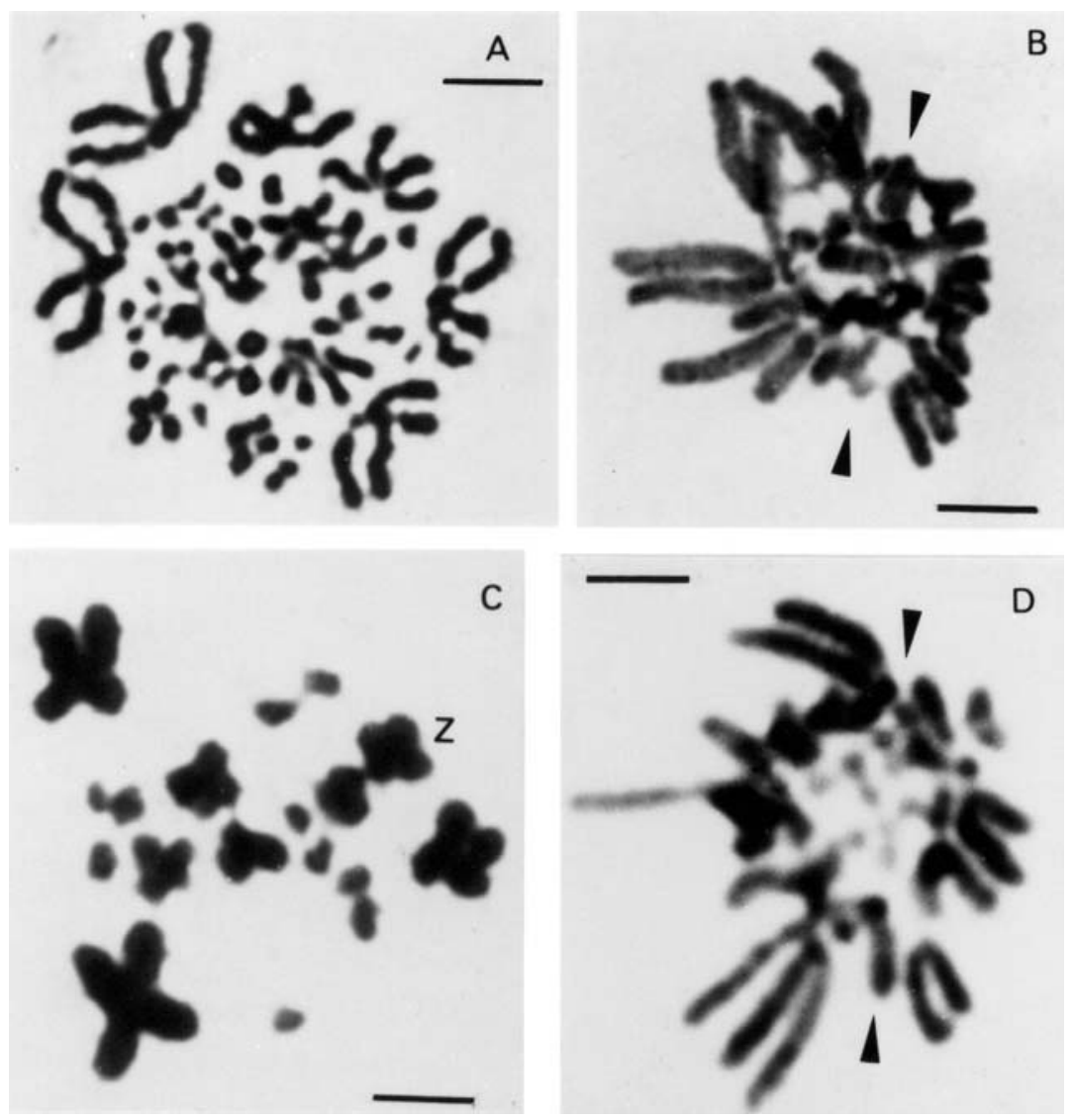

Fig. 3 - Groupal size-dependent chromosome positioning in Bothrops species: A. Somatic metaphase of $B$. moojeni with associated homologue chromosomes showing the larger group of chromosomes in the periphery of the nucleus (male; bar $=9.4 \mu \mathrm{m}$ ); $\mathrm{B}$. Asymmetric aspect of a somatic anaphase/telophase of $B$. jararaca with chromosome ordered by size (arrowheads indicate the axis of asymmetry; female 3; bar $=10.6 \mu \mathrm{m}$ ); C. Metaphase II of B. jararaca with smaller microchromosomes circunscribed by larger macrochromosomes (male 9; bar $=7.3 \mu \mathrm{m}$ ); D. Anaphase I with asymmetrical configuration (arrowheads indicate the axis of asymmetry; female 3 ; bar $=5 \mu \mathrm{m}$ ).

presents four chromatids still connected in the centromeres or in the telomeres (Figures $4 \mathrm{~A}$ to $4 \mathrm{C}$ ). Following centromere splitting of the diplochromosomes in two elements, each daughter nucleus divides again producing two new nuclei, each one with eight dyads comparable to those of second metaphase of meiosis. Some of these new nuclei can appear with chromatids still connected at the telomeres (Figures 4D to 4F).

\section{Chromosome Aberrations in B. jararaca}

The finding of diplochromosomes led us to examine chromosome morphology and distribution in mitosis and meiosis. The specimens of B. jararaca presented normal cells and cells with unstable chromosomes resulting in intraindividual polymorphisms. This instability was detected in one chromosome of pairs 2 and 3. The unstable chromosome 2 showed either differences in size, presence of a secondary constriction or breakages which led to monosomies 

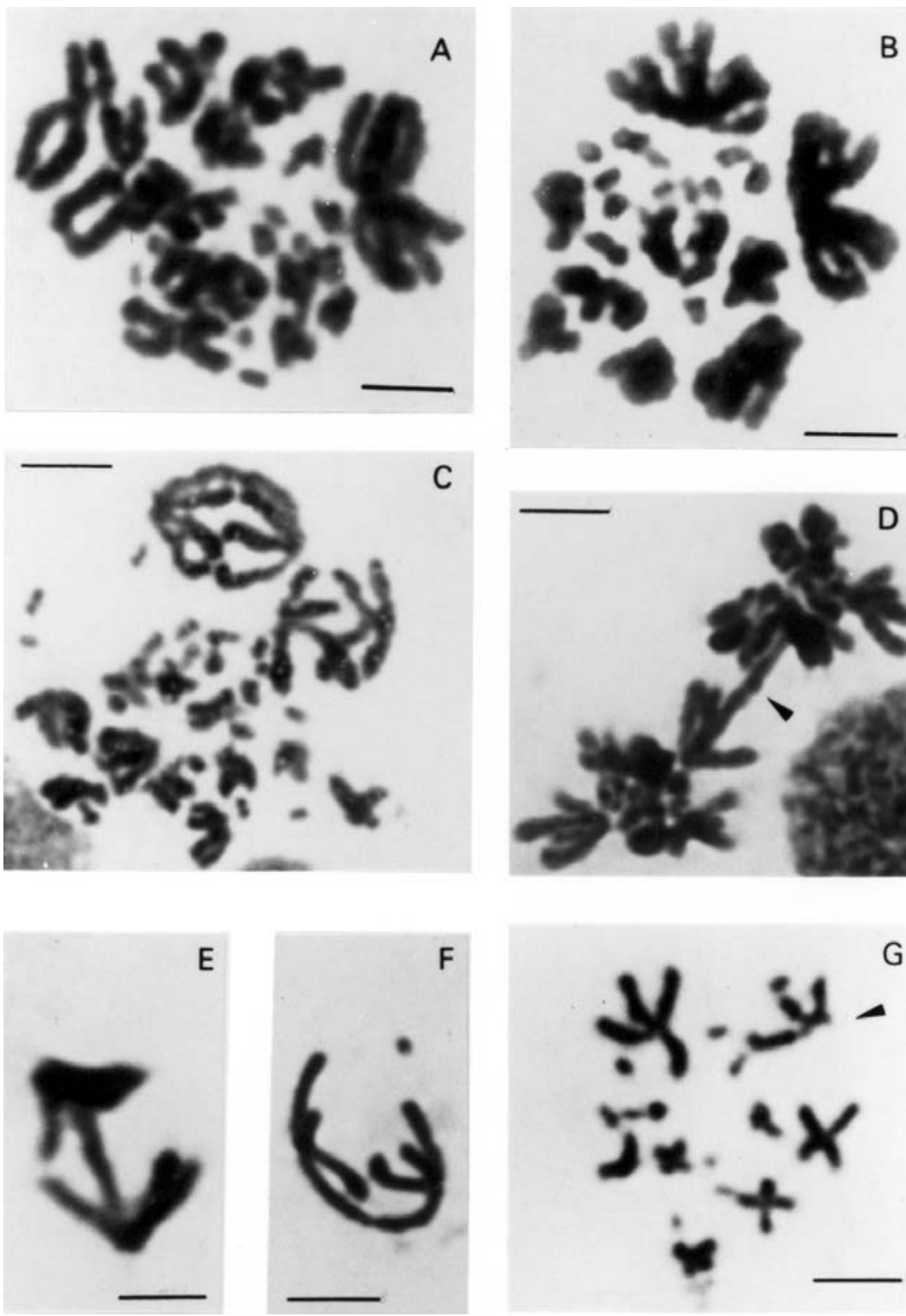

Fig. 4 - Diplochromosomes in Bothrops jararaca males: A, B and C. Three metaphase nuclei from a same specimen showing one set of diplochromosomes with four chromatids. These chromatids can appear connected in the centromere or splitted in two elements (male 12; A and B, bars $=7.9 \mu \mathrm{m} ; \mathrm{C}$, bar $=12.5 \mu \mathrm{m}$ ); D. Two daughter nuclei each one having dyads and presenting a telomere connection (arrowhead; male 13; bar $=9,3 \mu \mathrm{m}$ ); $\mathrm{E}$ and $\mathrm{F}$. Two inserts each showing one isolated diplochromosome with telomere connection (E, male 12; F, male 34; bars $=7.5 \mu \mathrm{m}$ ). G. A m II with dyad 2 showing a breakage in the long arm of one daughter chromosome (arrowhead; male 28 ; bar $=9.4 \mu \mathrm{m}$ ). 

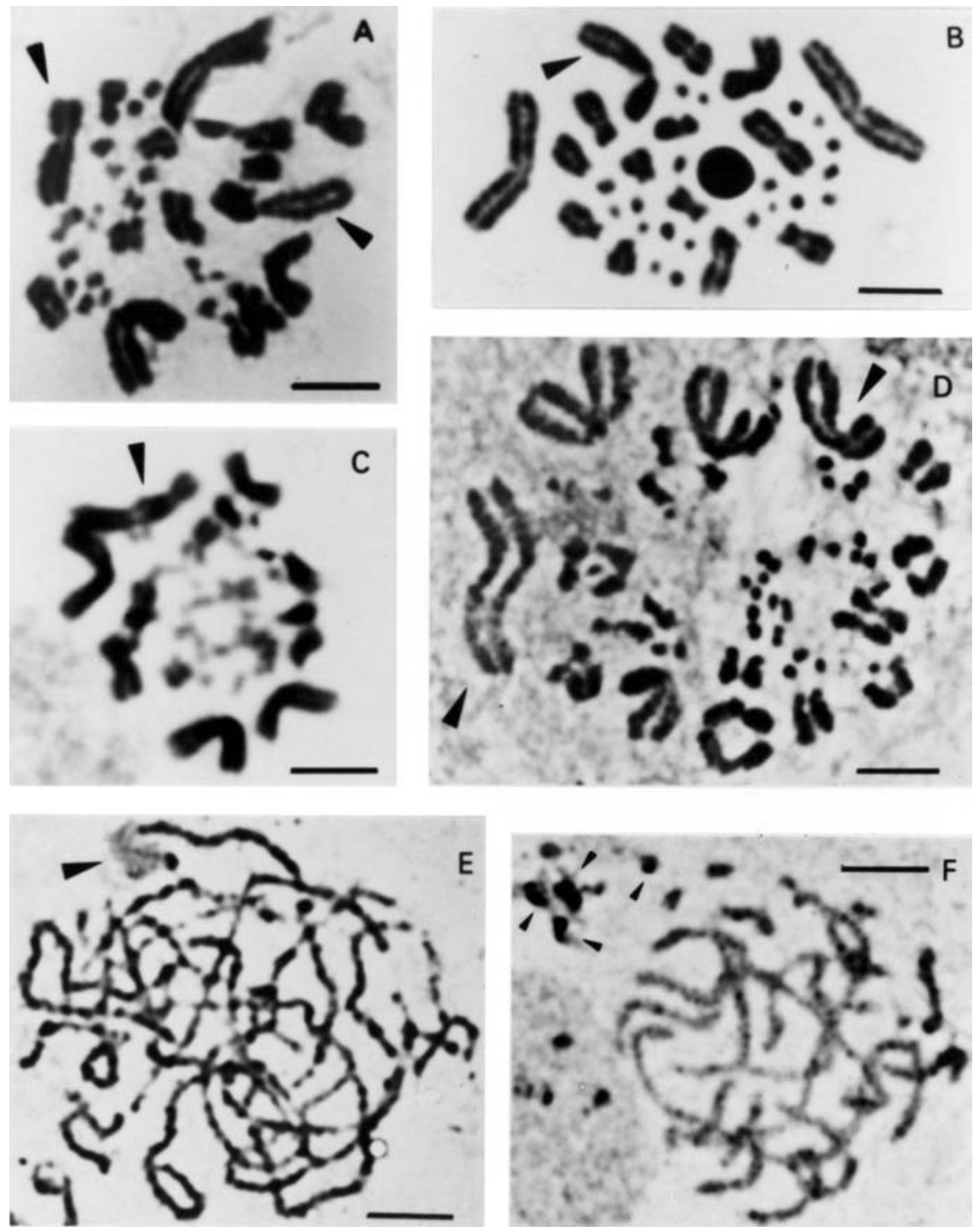

Fig. 5 - Chromosome unstability in spermatogonia metaphases of Bothrops jararaca from different populations: A. Size dimorphism of pair 2 (arrowheads; male 26; bar $=9.4 \mu \mathrm{m}$ ); B. Monosomy of chromosome 2 (arrowhead indicates the single chromosome 2; male 15; bar $=11.1 \mu \mathrm{m}$ ); C. Dimorphic chromosome 2 with a secondary constriction (arrowhead; male 28; bar $=9.3 \mu \mathrm{m})$; D. Size dimorphism of pair 2 (arrowhead; male 40; bar $=13.1 \mu \mathrm{m})$; E. A pachytene nucleus showing a large bivalent with or associated with a NOR (arrowhead; male 34 ; bar $=9.6 \mu \mathrm{m}$; AgAs staining); F. A somatic prophase exibiting NORs in four polarized microchromosomes (arrowheads; male 56 from Juquitiba; bar $=9.3 \mu \mathrm{m} ; \mathrm{AgAs}$ staining).

(Figures 5A to 5D). Abnormalities of chromosome 2 was observed in mitoses of nine males from: São Paulo State (three specimens from Cotia, Jundiaí, Ibiuna, and two from Juquitiba), three specimens from Paraná State, and one animal from Santa Catarina State (Canoinhas). One Paraná specimen with a polymorphic chromosome 2 also showed size polymorphism of pair 3. Polymorphism of pair 3 was 
also found in one female of unknown origin (Figure 1B).

The behavior of polymorphic pairs was analyzed in meiosis. In males besides apparently normal diplotenes with eight bivalents (8 II) $\mathrm{M}$, we found nuclei with bivalent 2 showing breakages, associations or exhibiting one arm completely open or only with telomere connection (Figures 6A to 6E). In females, we observed one or two chromosome bridges in first anaphase (Figures $6 \mathrm{~F}$ and $6 \mathrm{G}$ ). The female with a polymorphic pair 3 in mitosis (Figure 1B) presented one chromosome bridge in first meiosis (Figure 6G). Second metaphases studied in males appear either with 8 apparently normal dyads (M) (Figure 3C) or with a breakage in one arm of dyad 2 or lacking this dyad (Figure 4G). AgAs studies in males somatic cells showed NORs in one to two pairs of microchromosomes (Figure $5 \mathrm{~F}$ ). We also observed that a large macrochromosome can appear associated with a NOR in male pachytene nuclei. This macrochromosome seems to correspond to the unstable chromosome 2 (Figure 5E).

A complete quantitative analysis of both premeiotic events and meiosis in a same specimen is difficult because cell cycle is seasonal. In general the specimens exhibit only mitosis or meiosis. Yet, both cell types were observed in nine colchicine untreated males. The frequencies of mitotic and meiotic nuclei with endoreduplication and unstable chromosome 2 were estimated in this sample. The analysis of 592 nuclei included 173 mitoses, 297 diplotenes, and $122 \mathrm{~m}$ II (Table I). In mitosis, regarding the macrochomosomes three classes of nuclei were considered. Class A includes apparently normal diploid nuclei; class B has diploid nuclei with one unstable chromosome 2, and class $\mathrm{C}$ has endoreduplicated nuclei ( $\geq 4 \mathrm{n}$ and with aneuploidy). Among class $\mathrm{B}$ nuclei it was included those with dimorphism or monosomy of chromosome 2. Classes A, B, and $\mathrm{C}$ appeared with the frequencies of $57.2 \%, 14.4 \%$, and $28.3 \%$ respectively. In first meiosis, class A includes $80.8 \%$ of apparently normal nuclei with eight II; class B has $15.8 \%$ of abnormal nuclei with bivalent 2 unequal, broken or associated, and class $\mathrm{C}$ presents $3.4 \%$ of endoreduplicated nuclei with $\geq 16$ II (up to 64 II) and 15 II. An intriguing fact noted is that $\mathrm{m} \mathrm{I}=7 \mathrm{II}+1 \mathrm{I}$ were not observed though the occurrence of monosomic cells with $2 \mathrm{n}-1=$ 15. In second meiosis, class $A$ includes $69.7 \%$ of nuclei with eight apparently normal dyads; class B contains $17.2 \%$ of nuclei with eight dyads and presenting a breakage in one arm of dyad 2 or lacking this dyad, and class $\mathrm{C}$ has $13.1 \%$ of endoreduplicated nuclei. Among these endoreduplicated nuclei, 8.2\% presents 16 and 15 dyads lacking dyad 2. The remaining $4.9 \%$ of endoreduplicated $\mathrm{m}$ II includes nuclei with eight four-chromatids diplochromosomes.

\section{DISCUSSION}

We report here for the first time some peculiar cytological aspects of chromosome positioning and distribution in mitosis and meiosis of snakes with premeiotic endomitosis, reductional mitosis, altered meiosis, and aneuploidies. Regarding nuclei configurations, we describe that homologue chromosomes of premeiotic cells display two types of spatial order in the metaphase plate, positioned on opposite sides of the ring or closely apposed. This latter type is similar to the somatic pairing known in Diptera. Antiparallel and parallel aspects were found in eight and five nuclei respectively, in a total of 51 untreated nuclei (gonia cells) of B. jararaca. Among 24 colchicine treated cells, 11 nuclei showed bipolar configuration. In $B$. insularis, 23 nuclei presented complete bipolar aspect in a total of 76 colchicine treated cells. Among 12 untreated nuclei (spermatogonia cells) of this species, total antiparallelism and total parallelism appeared in one and two nuclei respectively. Considering that the random probability of complete parallel and complete bipolar distribution of the eight pairs of macrochromosomes is one in $2^{8}(1 / 256)$ in each case, the aspects here described cannot be explained as random events. In both configuration types the chromosomes have a constant groupal size-dependent distribution in mitosis and meiosis. The groupal size-dependent chromosome location observed in 

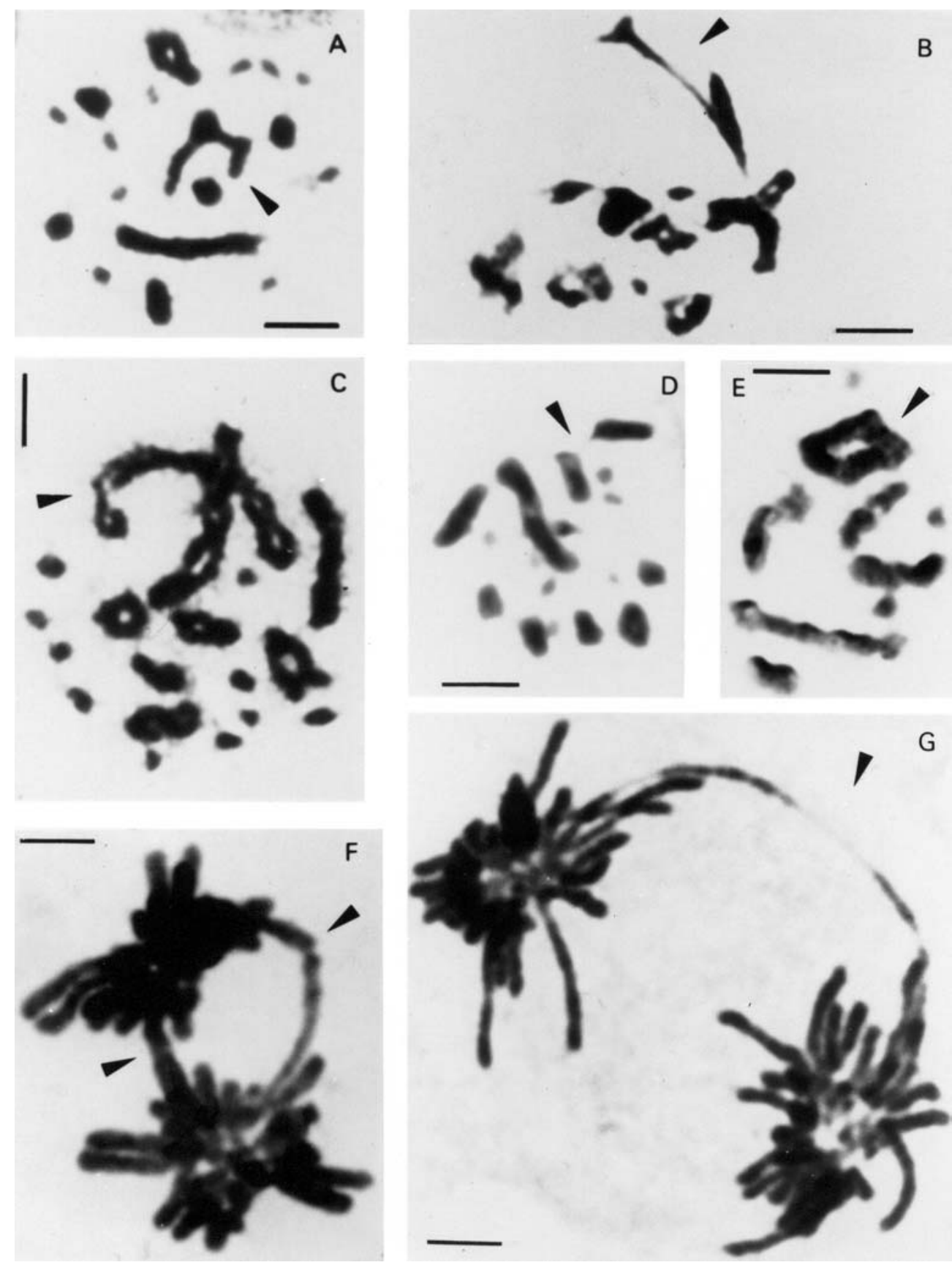

Fig. 6-Abnormal first meiosis of Bothrops jararaca from different populations: A. A diplotene nucleus with bivalent 2 open in one arm (arrowhead; male 4; bar $=12.5 \mu \mathrm{m}$ ); B. A first metaphase with bivalent 2 broken (arrowhead; male 26; bar $=10.2 \mu \mathrm{m}$ ); C. A diplotene nucleus with unequal bivalent 2 (arrowhead; male 36 from Paraná; bar $=8.9 \mu \mathrm{m}$ ); D. A diplotene nuclei with bivalent 2 broken (arrowhead; male 28; bar $=9.1 \mu \mathrm{m}$ ); E. A diplotene nuclei with chromosome 2 in a IV-like association (arrowhead; male 28; bar $=9.8 \mu \mathrm{m}) ; \mathrm{F}$. Two chromosome bridges in a first anaphase (arrowheads; female 3; bar $=7.1 \mu \mathrm{m}) ; \mathrm{G}$. A chromosome bridge in a first meiotic division (arrowhead; female 8; bar $=9.6 \mu \mathrm{m}$ ). 
TABLE I

Premeiotic and meiotic nuclei of Bothrops jararaca males with endomitosis and abnormalities of chromosome $22 \mathrm{n}=16 \mathrm{M}+20 \mathrm{~m}$ (noncolchicinized cells; only $\mathrm{M}$ were considered).

\begin{tabular}{|c|c|c|c|c|c|c|c|c|c|}
\hline \multirow{2}{*}{\multicolumn{2}{|c|}{$\begin{array}{l}\text { Number and } \\
\text { origin of the } \\
\text { animals }\end{array}$}} & \multirow{2}{*}{\multicolumn{2}{|c|}{$\begin{array}{c}\text { Total number } \\
\text { of cells }\end{array}$}} & \multicolumn{6}{|c|}{$\mathrm{M}$ i t o s i s } \\
\hline & & & & \multicolumn{2}{|c|}{$\begin{array}{c}\text { Class A: } \\
2 n=16\end{array}$} & \multicolumn{2}{|c|}{$\begin{array}{c}\text { Class B: } 2 \mathrm{n}=16 \\
\text { (with dimorphic } \\
\text { par 2) and } \\
2 \mathrm{n}-1=15\end{array}$} & \multicolumn{2}{|c|}{$\begin{array}{c}\text { Class C: } \\
\geq 4 n=32 \\
\text { and } \\
4 n-2=30\end{array}$} \\
\hline \multicolumn{2}{|l|}{28 Cotia - SP } & \multicolumn{2}{|l|}{117} & \multicolumn{2}{|c|}{12} & \multicolumn{2}{|c|}{8} & \multicolumn{2}{|c|}{9} \\
\hline \multicolumn{2}{|l|}{$26-\mathrm{PR}$} & \multicolumn{2}{|l|}{61} & \multicolumn{2}{|c|}{17} & \multicolumn{2}{|c|}{4} & \multicolumn{2}{|c|}{8} \\
\hline \multicolumn{2}{|c|}{12 Canoinhas - SC } & \multicolumn{2}{|l|}{106} & \multicolumn{2}{|c|}{10} & \multicolumn{2}{|c|}{2} & \multicolumn{2}{|c|}{6} \\
\hline \multicolumn{2}{|c|}{13 Ibiúna - SP } & \multicolumn{2}{|l|}{61} & \multicolumn{2}{|c|}{6} & 1 & & & \\
\hline 15 Jundiaí - S & & 40 & & & 28 & - & & & \\
\hline 27 Juquitiba - & & 31 & & & 7 & 1 & & & \\
\hline 9 Canoinhas - & & 66 & & & 11 & - & & & \\
\hline $34-\mathrm{PR}$ & & 34 & & & - & 6 & & & \\
\hline 40 Juquitiba - & & 76 & & & 8 & 3 & & & \\
\hline Total & & 592 & & & 99 & 25 & & & \\
\hline$\%$ & & - & & & $.2 \%$ & 14.4 & & & \\
\hline Number and & & Total nun & ber & & & $\mathrm{i} \mathrm{p} 1 \mathrm{o} t$ & $\mathrm{ne}$ & & \\
\hline $\begin{array}{l}\text { origin of the } \\
\text { animals }\end{array}$ & & of cell & & Cla & A: 8 II & $\begin{array}{r}\text { Class } \mathbf{E} \\
\text { (with } \\
\text { unequ } \\
\text { with bre }\end{array}$ & $\begin{array}{l}8 \text { II } \\
\text { I } 2 \\
1 \text { or } \\
\text { kage) }\end{array}$ & $\begin{array}{r}\text { Cla } \\
\geq \\
\mathrm{a} \\
1\end{array}$ & $\begin{array}{l}\text { C: } \\
6 \text { II } \\
\text { d } \\
\text { II }\end{array}$ \\
\hline 28 Cotia - SP & & 117 & & & 63 & 9 & & & \\
\hline $26-\mathrm{PR}$ & & 61 & & & 22 & 4 & & & \\
\hline 12 Canoinhas & $\mathrm{SC}$ & 106 & & & 12 & 10 & & & \\
\hline 13 Ibiúna - SF & & 61 & & & 30 & 9 & & & \\
\hline 15 Jundiaí - S & & 40 & & & - & 1 & & & \\
\hline 27 Juquitiba - & & 31 & & & 10 & - & & & \\
\hline 9 Canoinhas - & & 66 & & & 10 & 3 & & & \\
\hline $34-\mathrm{PR}$ & & 34 & & & 21 & 1 & & & \\
\hline 40 Juquitiba - & & 76 & & & 12 & 10 & & & \\
\hline Total & & 592 & & & 40 & 47 & & & \\
\hline$\%$ & & - & & & $8 \%$ & 15.8 & & & \\
\hline ber and & Tot & 1 number & & & e c o & $\mathrm{d} \mathrm{d} \mathrm{m} \mathrm{e}$ & $\mathrm{t}$ a p & a s & \\
\hline n of the & & f cells & Cla & A: & Class & : 8 dyads & & Clas & \\
\hline tals & & & & & $\begin{array}{l}\text { (with } \\
\text { in c } \\
\text { and }\end{array}$ & $\begin{array}{l}\text { reakage } \\
\text { yad 2) } \\
\text { dyads }\end{array}$ & $\begin{array}{r}\geq 16 \\
a \\
15\end{array}$ & $\begin{array}{l}\text { lyads } \\
\text { d ads }\end{array}$ & $\begin{array}{c}8 \text { diplo- } \\
\text { chromo- } \\
\text { somes }\end{array}$ \\
\hline Cotia - SP & & 117 & & 3 & & 4 & & & 1 \\
\hline PR & & 61 & & & & 3 & & & - \\
\hline Canoinhas - SC & & 106 & & & & 9 & & & 3 \\
\hline Ibiúna - SP & & 61 & & 5 & & 4 & & & - \\
\hline Jundiaí - SP & & 40 & & 8 & & 1 & & & - \\
\hline Juquitiba - SP & & 31 & & 2 & & - & & & - \\
\hline anoinhas - SC & & 66 & & 7 & & 1 & & & - \\
\hline - PR & & 34 & & 2 & & - & & & 1 \\
\hline Juquitiba - SP & & 76 & & 4 & & 2 & & & 1 \\
\hline & & 592 & & 5 & & 21 & & & 6 \\
\hline & & - & & $7 \%$ & & $.2 \%$ & & & $4.9 \%$ \\
\hline
\end{tabular}


meiosis and mitosis of $B$. jararaca seems to indicate that chromosome order is maintained through cell divisions. This conclusion gives support to data showing that the relative chromosomal position on each individual metaphase ring seems to be carried through anaphase into telophase (Allison and Nestor 1999). Our interpretation also support the mitotic preset biophysical model which assumes that chromosome-size-dependent positioning is established and maintained in mitosis and G1 interphase (Sun et al. 2000). As to the presence of two antagonic aspects of nuclei configuration in a same tissue (gonia cells) we suppose it may reflect the occurrence of two cells types. Nagele et al. (1999) suggest the coexistence of two cellular subclones to explain preparations exhibiting simultaneously human cells with chromosomes 8 and 11 apposed and cells with these chromosomes widely separated. High frequencies of translocations among certain chromosomes may be related to the fact they are adjacent on the chromosome rosette (Nagele et al. 1995). As we used squash technique, the different positions of the metaphase plates may result in alterations of the final figures. In some cases parallel configurations may appear as antiparallel or vice versa. Although our conclusions are mainly based on morphological evidences, the use of more precise techniques as painting and 3-D analysis could be helpful to confirm our observations. Until now these assays were not used for snakes because in this group of animals molecular markers are still not available as for chromosomes of human and other mammals.

Our findings that premeiotic cells of B. jararaca with somatic pairing and endomitosis also present altered meiosis and chromosome aberrations led us to consider whether these events could be correlated. It is known that diplochromosomes were found in spermatogonia mitosis of Locusta migratoria in experiments using radiation or other agents (White 1935, 1973). The homologue diplochromosomes observed in premeiotic cells of $B$. jararaca showed peculiar behavior, segregating to opposite poles in cell division. This fact observed in $4.9 \%$ of $\mathrm{mII}$ may indicate that first meiotic division would be suppressed. Suppression of first meiosis division is known in Rana esculenta, a hybrid species between $R$. ridibunda and $R$. lessonae. In this case, meiosis is preceded in males and females by elimination of the $R$. lessonae genome, followed by doubling of $R$. ridibunda genome. By this way only $R$. ridibunda gametes are formed. Meiotic pairing in the hybrid occurs between sister chromosomes without linkage groups recombination (Heppich et al. 1982). Yet, in non-hybrid species with few exceptions, at first meiosis the two homologues of a pair move to opposite poles and non-homologous pairs segregate independently of each other. In Drosophila melanogaster, female non-random segregation of nonhomologues might occur when chiasma formation has failed to occur (Grell 1969). Further, it was demonstrated that the Nod kinesin-like protein is specifically required for achiasmate chromosome segregation in Drosophila melanogaster (Zhang et al. 1990). Also it was shown that $\alpha$-tubulin 67C gene impair achiasmate chromosome segregation in this species (Matthies et al. 1999). According to our assumption, the cells with somatic pairing and premeiotic endoreduplication would enter directly to second meiosis division ( $\mathrm{m} \mathrm{II}$ ). In this case, the $\mathrm{m}$ II $=7$ dyads $(\mathrm{M})$ would be explained by the elimination of the unstable parental four-chromatids diplochromosome. Although $2 \mathrm{n}-1=15$ cells were found, the absence of diplotene and of first metaphases with univalents ( $\mathrm{m} \mathrm{I}=7 \mathrm{II}+1 \mathrm{I}$ ) could be explained by this assumption. Accordingly, in false first meiosis the endoreduplicated homologues remain connected as dense cylindral structures. These complex structures do not reveal clear splitting of the parental homologues as well as do not show clear chiasmata aspects. Yet, diplotene nuclei with visible chiasmata were also observed. In this case it remains to be explained whether these chiasmata are true exchanges between homologue chromosomes or produced by sister chromatid recombinations in diplochromosomes.

The dimorphism of chromosomes, probably the $2^{\text {nd }}$ or $3^{\text {rd }}$ pairs, may explain the presence of unequal bivalents and of chromosome bridges in first 
meiosis. The observation that a large macrochromosome bivalent is associated with a NOR in meiosis of animals with a dimorphic chromosome 2 in mitosis may indicate that the abnormalities could be caused by translocations involving a NOR. Nonhomologous association of nucleolar chromosomes in human may be accounted for certain non-disjunctions and translocations causing diseases, as in myeloid leukemia (Ohno et al. 1961). That model was supported by further studies using the electron microscope to study human meiotic cells (Stahl et al. 1983). Moreover, the analysis of Robertsonian translocations in mice indicated that fusion of nucleoli is not the key factor predisposing to centric fusions (Miller et al. 1978). According to these authors, Robertsonian translocations may result from close association of heterochromatin and the nucleoli. The chromosome bridges observed in anaphase I of snakes could result from breakage-fusion events in the nucleolar organizing region, as previously suggested (Newman 1966). These translocations can be of insertion type. Unequal crossing-over would result in duplications and deletions producing morphological and genetical alterations in the chromosomes involved. The eventual presence of a hotspot could enhance this phenomenon. Reiter et al. (1996) found such a hotspot inside the region involved in unequal crossing-over in human chromosome 17 and sequence analysis revealed a insect mariner transposon-like element (MITE) near the hotspot which could mediate the strands exchange. Alternatively, we may suppose that in endomitotic nuclei a more prolonged S-phase due to successive rounds of DNA replication could increase heterochromatic associations, predisposing to translocations. According to Csink and Henikoff (1998), in Drosophila the heterochromatin can influence the relative position of a chromosomal region during interphase and length increase of G I phase allows heterochromatic association.

Though the exact mechanism that operates in B. jararaca chromosome abnormalities is not understood, we postulate that the parallel configuration and endomitosis could be correlated to the chro- mosomal aberrations. These aberrations could result from translocations involving the NOR or the heterochromatin in telomeric associations between nonhomologue chromosomes. Too, aberrations and mutations induced by deleterious ambiental agents cannot be excluded. We assume the occurrence of a "mixed" gonad with heterozygous cells and unequal transmission of a member of a pair of homologe chromosomes. Nevertheless, we cannot dismiss the possibility that the chromosome aberrations could result from complex translocations which heterozygosis would be maintained in natural populations by suppression of first meiosis. Again changes in the meiotic mechanism in a sexually reproducing organism are not frequent. There are some instances of two types of meiosis occurring in the same gonad. According to White (1973), some of these alterations probably experienced special gonad regions rather than the whole gonad. In this case, the premeiotic doubling would be a prerequisite to originate parthenogenetic species such as the triploid salamanders (Sessions 1982) and lizards (Cuellar 1978).

\section{ACKNOWLEDGMENTS}

We thank Laerte Paula Santos, Nair Aparecida Silva Pereira, Heitor Costa, and Luiz Antonio Tadeu Dias for technical help; Helir Serralvo for photomicrography and editorial help. This work was supported by CNPq, FAPESP and Fundação Butantan.

\section{RESUMO}

O posicionamento dos macrocromossomos de Bothrops jararaca e Bothrops insularis (Viperidae) foi estudado em metáfases radiais não alteradas de células não cultivadas (espermatogônias e oogônias) não submetidas a inibidores do fuso. Metáfases colchicinizadas de tecidos não cultivados (baço e intestino) e cultivados (sangue) foram também analisadas. Relatamos dois arranjos cromossômicos antagônicos não casuais em células premeióticas não tratadas: a configuração paralela, com cromossomos homólogos associados lado a lado na placa metafásica, e a configuração antiparalela, tendo os cromossomos homó- 
logos com distribuição antipolar no anel metafásico. O aspecto antiparalelo apareceu também em células colchicinizadas. O arranjo espacial dos cromossomos em ambas configurações é grupal, dependente do tamanho e mantido na meiose. Descrevemos também endomitoses seguidas de mitoses reducionais que restabelecem o número diplóide em gônias não tratadas. Em machos de B. jararaca observamos alterações no mecanismo meiótico em algumas regiões da gônada. Neste caso, as células endoreduplicadas segregam os diplocromossomos para polos opostos, formando diretamente metáfases da segunda divisão da meiose com supressão da primeira divisão. Numa divisão sucessiva, estas metáfases formam núcleos com um conjunto de cromossomos. Duplicação cromossômica em oogônias é conhecida em espécies híbridas e em salamandras e lagartos partenogenéticos. Bothrops jararaca também apresentou rearranjos cromossômicos, ocasionando aneuploidias na mitose e meiose. Sugerimos que o pareamento somático, a endomitose, as alterações da meiose e as aberrações cromossômicas podem ser processos correlacionados. Aspectos similares de configurações nucleares, endomitose e mitose reducional foram encontrados em outras espécies de Viperidae e Colubridae.

Palavras-chave: serpentes, pareamento somático, posicionamento cromossômico, endomitose, diplocromossomos.

\section{REFERENCES}

Allison DC AND Nestor AL. 1999. Evidence for a relatively random array of human chromosomes on the mitotic ring. J Cell Biol 145: 1-14.

BAJer AS ANd Molè-Bajer J. 1981. Mitoses: studies of living cells: a revision of basic concepts. In Mitoses/Cytokineses. AM Zimmerman and A. Forer, editors, Academic Press, New York. 227-299.

BeçaK ML and BeçaK W. 1973. Chromosome secondary constriction in different stages of development. Experientia (Basel) 29: 359-361.

BeÇAK ML AND BEÇAK W. 1981. Behavior of the ZW sex bivalent in the snake Bothrops jararaca. Chromosoma (Berl.) 83: 289-293.

BeçaK ML, BeçaK W, Roberts FL, Shoffner RN AND Volpe EP. 1971. Chromosome Atlas: Fish, Amphibians, Reptiles and Birds. vol. 1 Ed. K. Benirschke and TC. Hsu. Springer-Verlag. Berl.
Beçak ML, Rabello-Gay MN, Beçak W, Soma M, Batistic RF and Trajtengertz I. 1990. The W chromosome during the evolution and in sex abnormalities of snakes. DNA content, $\mathrm{C}$ banding. Cytogenetics of Amphibians and Reptiles. Birkhauser Verlag. Basel.

BEÇAK W. 1968. Karyotypes, sex chromosomes and chromosomal evolution in snakes. In Venomous Animals and their Venoms. W. Bucherl, E. Buckley and V. Deulofeu, editors. Vol. I, p. 53-95. Academic Press, New York.

BeÇaK W and BeçaK ML. 1969. Cytotaxonomy and chromosomal evolution in Serpentes. Cytogenetics 8: 247.

Beçak W, Beçak ML and Nazareth HRS. 1962. Karyotypic studies of two species of South American snakes (Boa constrictor amarali and Bothrops jararaca). Cytogenetics 1: 305-313.

BeçaK W, BeçaK ML and Nazareth HRS. 1966. Evolution and sex chromosomes in Serpentes. Mem Inst Butantan 33: 151-152.

Bennett MD. 1984. Premeiotic events and meiotic chromosome pairing. Society for Experimental Biology 87-121.

Costello DP. 1970. Identical linear order of chromosomes in both gametes of acoel turbellarian Polychoerus carmelensis: a preliminary note. Proc Nat Acad Sci USA 67: 195-1958.

Csink AK And Henikoff S. 1998. Large-scale chromosomal movements during interphase progression in Drosophila. J Cell Biol 143: 13-22.

Cuellar O. 1978. Parthenogenetic lizards. Science 201: 1115.

DobZhansky TH. 1936. The persistence of the chromosome pattern in successive cell divisions in Drosophila pseudoobscura. J Exp Zool 74: 119-135.

Grell RF. 1969. Meiotic and somatic pairing. Chapter 6, pp. 361-492. In Genetic Organization, I. EW Gaspari and AW Ravin editors. New York: Academic Press.

Heppich S, Tunner HG and Greilhuber J. 1982. Premeiotic chromosome doubling after elimination during spermatogenesis of the species hybrid Rana esculenta. Theoretical and Applied Genetic 61: 101-104.

Hiraoka Y, Agard DA and Sedat JW. 1990. Temporal and spatial coordination of chromosomal movement, spindle formation, and nuclear envelope breakdown 
during prometaphase in Drosophila melanogaster embryos. J Cell Biol 111: 2815-2828.

JURICEK DK. 1975. Non-random chromosome distribution in radial metaphases from the Chinese Hamster. Chromosoma (Berl.) 50: 313-326.

MANuelidis L AND Borden J. 1988. Reproducible compartmentalization of individual chromosome domains in human CNS cell revealed by in situ hybridization and three dimensional reconstruction. Chromosoma (Berl.) 96: 397-410.

Matthies HJG, Messina LG, Namba R, Greer KJ, Walker MY and Hawley RS. 1999. Mutations in the $\alpha$-tubulin 67C gene specifically impair achiasmate segregation in Drosophila melanogaster. J Cell Biol 147: 1137-1144.

Miller OJ, Miller DA, Tantravahi R and Dev VG. 1978. Nucleolus organizer activity and the origin of Robertsonian translocations. Cytogenetics. Cell Genet 20: 40-50.

Moreno R, Navarro J, Iturra P and Veloso AM. 1987. The karyotype of Philodryas chamissonis (Colubridae). Identification of nucleolar organizer region (NOR) and sex chromosomes by banding methods. Braz. J Genetics 3: 497-506.

Mosgöller W, Leitch AR, Brown JKM AND HeslopHARRISON JS. 1991. Chromosome arrangements in human fibroblasts at mitosis. Human Genetics 88: 27-33.

Nagele R, Freeman T, McMorrow L and Lee H. 1995. Precise spatial positioning of chromosomes during prometaphase: evidence for chromosome order. Science 270: 1831-1835.

Nagele RG, Freeman T, McMorrow L, Thomson Z, Kitson-Wind K and Lee H. 1999. Chromosome exhibit preferential positioning in nuclei of quiescent human cells. J Cell Sci 112: 525-535.

NewMan LJ. 1966. Bridge and fragment aberrations in Podophillum peltatum. Genetics 53: 55-63.

Ohno S, Trujillo JM, Kaplan WD and Kinosita P. 1961. Nucleolus-organizers in the causation of chromosomal anomalies in man. Lancet II: 123-125.
RABL C. 1885. Uber Zelltheilung. Morphol Jahrbot 10: 214-330

Reiter LT, Murakami T, Koeuth T, Pentao L, Muzny DM, GiBBS RA AND LUPSKI JR. 1996. A recombination hotspot responsible for two inherited peripheral neuropathies is located near a mariner transposonlike element. Nature Genetics 12: 288-297.

SESSIONS SK. 1982. Cytogenetics of diploid and triploid salamanders of the Ambystoma jeffersonianum complex. Chromosoma (Berl.) 84: 599-621.

Singh L, Ray-Chaudhuri SP, Majumdar K, Purdom IF AND Jones KW. 1979. Sex specific chromosome polymorphisms in the common indian krait, Bungarus caeruleus Schneider (Ophidia, Elapidae). Chromosoma (Berl.) 73: 93-108.

Stahl A, Luciani JM, Hartung M, Devictor M, Bergé-Lefranc JL and Guichaoua M. 1983. Structural basis for Robertsonian translocation in man: association of ribosomal genes in the nucleolar fibrillar center in meiotic spermatocytes and oocytes. Proc Nat Acad Sci USA 80: 5946-5960.

Sun HB, Shen J And Yokota H. 2000. Size-dependent positioning of human chromosomes in interphase nuclei. Biophis J 79: 184-190.

Trajtengertz I, BeçaK ML and Ruiz RG. 1995. Ribosomal cistrons in Bothrops neuwiedi (Serpentes) subspecies from Brasil. Genome 38: 601-606.

Vidal BC and Mello MLS. 1995. Re-evaluating the AgNOR staining response in Triton X-100- treated liver cells by image analysis. Anat Cell Pathol 9: 39-43.

White MJD. 1935. The effects of X-rays on mitosis in the spermatogonial divisions of Locusta migratoria L. Proc Roy Soc Lond B 119: 61-84.

White MJD. 1973. Animal Cytology and Evolution (3 ed.). Cambridge University Press, 961pp.

Zhang P, Knowles BA and Goldstein LS. 1990. A kinesin-like protein required from distributive chromosome segregation in Drosophila. Cell 62: 10531062. 